\title{
REVEALING THE MEANING OF BAI 'AND TIJARAH IN AL-QUR'AN (INTERPRETATION OF ECONOMIC VERSES)
}

\author{
Farid Ikhwanuddin ${ }^{1}$, Roni Hidayat ${ }^{2}$
}

\author{
${ }^{1}$ SEBI Email : faridikhmwanuddin@gmail.com \\ ${ }^{2}$ SEBI Lecturer \& Doctoral Candidate UIN Syarif Hidayatullah Email \\ ronihidayat.ma@gmail.com
}

\begin{abstract}
One form of economic activity carried out by humans is trade. It can be said that trade is the oldest activity carried out by humans in fulfilling their daily needs. Mecca at that time was a major international trade and shopping center, and Islam was born in the militia of Mecca trade. Once the Islamic attachment to trading activities, many narratives of the verses of the Qur'an seemed to be directed at the merchants. Qur'an was first addressed to the merchants reflected in the language and ideas". More specifically, disclosure of trade in the Qur'an can be found through lafadz bai 'and tijarah. In the following article a thematic review of lafadz bai 'and tijarah and its derivatives is presented, which is analyzed using the Makkiyyah and Madaniyyah studied tematic. In the Qur'an the verses which reveal lafaz bai 'in various variations are contained in eleven verses scattered in different letters, while the Disclosure of lafadz tijarah in the verses of the Qur'an is mentioned eight times in seven letters. The form of disclosure of the Lafadz is entirely the same in the form of mashdar (تجارة).
\end{abstract}

Keywords: Economy, Al-Qur'an, Bai ', Tijarah

\section{INTRODUCTION}

Trade activities are activities that are familiar to Muslims. Such is the attachment of Islam to trading activities (W. Montgomery Watt, 1998, pp. 5-6) describing the fact that the Quran is first addressed to the merchants is reflected in its language and ideas. The terms are used to express the fundamentals of the doctrine and not only as a figurative language to clarify the description.

Among these affirmations of the Quran are that human actions are recorded in a book. Moreover, Judgment Day is a day of accountability. Also, everyone receives his share, and there is a balance sheet calculation (as in the exchange of money and goods), and each person's actions are weighed. Furthermore, every soul is responsible for the deeds he does; if a person's actions are approved, he will receive a salary; Also, supporting the struggle of the Prophet is equivalent to giving a loan to Allah.

In the Quran, trade disclosure can be found through lafadz bai and tijarah. Understanding the conception of bai and tijarah in the Quran becomes essential. The significance of studying the object of this study is the undeniable reality that Islam as one of the religions embraced by billions of people on earth, so it 
Jurnal Ekonomi dan Perbankan Syariah

Vol. 7. No.2, 0ktober 2019: 34-46, ISSN (cet): 2355-1755 | ISSN (online): 2579-6437

| 35

becomes essential to look for the meaning of bai 'and tijarah according to what is shown in the Koran by looking at its historical scope, namely with the guidance of the transition verses makkiyyah and madaniyyah (Lutfi, 2011, p. 64).

\section{LITERATURE REVIEW}

\subsection{AL-BAI 'IN THE QURAN}

The word bai' written in Arabic بيع is a mashdar derived from the word باع, etymologically meaning to give. More specifically, Imam Raghib al-Isfahani interpreted bai' by giving an item by taking the price of the goods given. In other words, bai' means selling goods. Likewise, Ibn Manzur in lisan al-Arab defines bai' as an activity of selling and buying goods at a predetermined price. The word bai' with the form of the name buyu has become a technical term in the fiqh field. The word means the exchange of property (money and commodities) for mutual ownership. (Lutfi, 2011, p. 67)

Aside from being a means of buying and selling, the word bai' also means a real promise, taking an oath. This definition is familiar in Indonesian as bai'at. The term bai'at is absorption from Arabic بيعة. The word بيعة which is composed of letters (بيعات-بيع) (البيعة) which means the place of worship of Christians and Jews. (Ma'luf, 2000, p. 57).

The definition of selling and purchasing in syara is an agreement to exchange goods or goods that have a value in a mutual agreement between the two parties that one receives the objects and the other party also accepts them following the agreement or provisions which are justified by the syara and agreed. Buying and selling also means "exchanging something for something". Other words from al-bai' are ash-syira', al-mubadalah, and at-tijarah. (Suretno, 2015, hlm. 94). Buying and selling in terms of fiqh is called $a l$-bai', while al$b a i^{\prime}$ is the sale and purchase of objects with objects, or the exchange of objects with money. While according to the book Fath al-Muin the word al-bai' is defined as بaccording to the lugoh term: "exchanging something for something (other)" (Wahyuningsih, 2012, hlm. 17-33). In Surah Al-Baqarah 275:

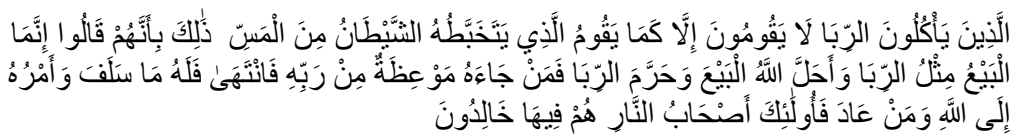

Meaning: Those who swallow usury cannot rise up save as he ariseth whom the devil hath prostrated by (his) touch. That is because they say: Trade is just like usury; whereas Allah permitteth trading and forbiddeth usury. He unto whom an admonition from his Lord cometh, and (he) refraineth (in obedience thereto), he shall keep (the profits of) that which is past, and his affair (henceforth) is with Allah. As for him who returneth (to usury) - Such are rightful owners of the Fire. They will abide therein. 
36 | Farid Ikhwanuddin, Roni Hidayat : Zahrotul Millah: Revealing the Meaning of Bai' and Tijarah in Al-Qur'an (Interpretation of Economic Verses)

\section{B. TIJARAH IN THE QURAN}

Disclosure of trading activities in the Qur'an besides using the word bai' also uses the word tijarah. The word tijarah, as stated by Ibn Manzur is mashdar which means to sell and buy, or it can be said as trading or trading activities. Imam Raghib Isfahani, understands pilgrimage as an activity of selling and buying something to get profit or to use capital to get profit. In economics, trade is conventionally defined as a process of exchange based on the voluntary will of each party. Those involved in trading activities can determine the advantages and disadvantages of free exchange. (Jusmaliani, 2008, p. 45). However, the basic principle of trade, according to Islam, is the element of freedom in conducting exchange transactions, but the activity is still accompanied by the hope of obtaining the pleasure of Allah. Furthermore, coercion is prohibited. Therefore, in order to obtain harmony in the trading system, moral trade is needed, namely honest and fair trade, and not harming both parties (Lutfi, 2011, hlm .61-85).

The word tijarah is derived from the word tajara-yatjuru-tajran-tijaratan which means to trade, trade, trade, commerce. Pilgrimage covers bai' and syira' (buying and selling) intending to make a profit. According to the Big Indonesian Dictionary, trade is work related to selling and buying goods for profit, buying and selling, commerce. Trading is the same as buying and selling, trading. Trading business, commercial business in the world of commerce, business fields. The verses of pilgrimage are found in Surah Al-Baqarah: 16,282; An-Nisa ': 29; At-Taubah: 24; Al-Nur: 37; Fatir: 29; As-Shaf: 10; Al-Jum'ah: 11. The verses bai' are found in Surah Al-Baqarah: 254, 275, 282; Ibrahim: 31; AlJum'ah: 9.7 While syira' is contained in the Q.S. Al-Baqarah: 16, 41, 79, 86, 90, 102, 174-175; Ali Imran: 177, 187, 199; An-Nisa ': 44; Al-Maidah: 44; AtTaubah: 9, 11; Yusuf: 95, and Luqman: 6. (Khuza, 2005, hlm. 36-48).

According to Ar-Raghib Al-Asfahani, tijarah means spending capital to make a profit. In the interpretation of Al-Jami 'li Ahkam Al-Quran, Al-Qurthubi states that tijarah is an exchange in any way that is following sharia'. In addition to usury and exchange damaged, such as wine, pigs, and blood. Of the several understandings of pilgrimage that have been explained, the last understanding, put forward by Al-Qurthubi seems to be adequate and covers various aspects. That pilgrimage (commerce, trade, business) is not just a transaction for profit, but more than that, that the activity of the transaction follows the correct law, namely the Divine Shari'ah.

\section{RESEARCH METHODOLOGY}

This type of research used in this study is qualitative research with a descriptive approach that is by describing data obtained directly. The data used by the authors are secondary data obtained through a literature study approach, which is relevant that is available in books, journals, internet sources, and so on relating to bai 'and pilgrimage. 
Jurnal Ekonomi dan Perbankan Syariah

Vol. 7. No.2, 0ktober 2019: 34-46, ISSN (cet): 2355-1755 | ISSN (online): 2579-6437

\section{7}

\section{DISCUSSION}

\subsection{Meaning of $B a i^{\prime}$ in the verses of the Quran}

\subsubsection{The meaning of bai' in Surah Ibrahim (14): 31}

The Lafadz used in this verse is (بي)

a. In this verse, we can understand the meaning of bai' as a sale and purchase activity in which there is a process of exchange (redemption) of something for something.

b. Talk about Allah's commands to establish prayers and give alms.

c. In this verse, Allah reminds people that the deadline for people to do an action (in this case, prayer and giving alms) is with the coming of doomsday.

When the Day of Judgment arrives, then one's deeds will not be noticed. On the Day of Judgment, there will be no trading or redemption of charitable deeds so that they can be considered for the record.

\subsubsection{The meaning of bai' in Surah al-Baqarah (2):254.}

\section{Lafadz used is بيع}

a. Meaning bai' in this verse, there is no more buying and selling transactions on the day when the end of the world comes. Humans are required to do good deeds for the afterlife while living their lives in the world

b. Humans must maximize their assets to be converted in the way of goodness because on the Day of Judgment; there will be no redemption process to redeem or sell and buy.

Ar-Razi provides the further explanation that bai 'in this verse has two meanings. First, bai 'means fidyah (ransom), in the sense that on that day, there was no transaction process of redemption from sin that someone had done. The second meaning 'bai' is the activity of buying and selling, in the sense that the verse instructs people to use their possessions in the way of Allah before the day comes when there is no trade and sale and sale that can produce from the assets they have.

\subsubsection{The meaning of $\mathrm{bai}^{\prime}$ in Surat al-Baqarah (2): 275}

Lafadz that appears in this verse is; البيع.

The meaning of this verse is to talk about the different activities that occur between bai 'and usury. There are two kinds of usury: nasiah and fadl. Usury nasiah is the overpayment required by the lender. Usury Fadl is the exchange of an item for similar goods, but more in number because the person exchanging requires it. This verse means riba is double usury nasiah and is common in Arab society in the jahiliah era. Thus, it can be understood that there are differences between buying and selling and usury. An honest sale and purchase are what is ordered to be done, not a fraudulent sale and purchase that takes multiple benefits for one party and harms the other party, because this can fall into the practice of usury. 
38 | Farid Ikhwanuddin, Roni Hidayat : Zahrotul Millah: Revealing the Meaning of Bai' and Tijarah in Al-Qur'an (Interpretation of Economic Verses)

\subsubsection{The meaning of bai' in Surat al-Baqarah (2): 282 .}

تبايع

a. The meaning in this verse is to explain the buying and selling activities that require testimony in the implementation.

b. Order to write honestly and fairly the transaction activities carried out.

It is necessary to witness and write up the activities of sale and purchase transactions carried out to get an excellent buying and selling activity. This requirement is to avoid fraud or loss that will be suffered either by the seller or the buyer. This condition leads to proper forms of buying and selling, namely honesty and fair buying and selling and not harming both parties.

\subsubsection{The meaning of bai' in Surat al-Hajj (22): 40.}

The disclosure of the lafadz is not in the form of bai', but reads it by giving a kasrah punctuation in the letter $b a^{\prime}$ so that it reads as; In the interpretation of ibn Kathir the meaning of this verse is a place of worship for Christians or Jews, Ibn Kathir who gave the interpretation that the lafadz بَيَع was some scholars interpreted it as a place of worship of Christians, some others interpreted it as a place of worship of Jews. In general, the context of the verse in Surat alHajj (22): 40 speaks of permission to fight for the believers.

Ikrimah, adh-Dhahhak, and Qatadah said: "Surely they are the Jewish churches and they call them blessings. While the mosques are for Muslims. His Word: yudzkaru fii Has mullaa Hi katsiiran ("In which many are called the name of Allah.").

\subsubsection{The meaning of $b a i^{\prime}$ in Surat al-Fath (48): 10 and 18 .}

In both verses above the expression of lafadz is in the form; يبايع. The meaning of lafadz means the promise of loyalty (bai'at). The context of this verse deals with the Hudaibiyah incident. Tabari (vol. XXII: 209). In the month of Dhulkaidah the sixth year of the Hijri of the Prophet Muhammad and his followers visited Mecca to perform Umrah and see their families who had long been abandoned. Arriving at Hudaibiyah he stopped and sent 'Uthman bin Affan first to Makkah to convey the intention of his and his arrival of the Muslims. They awaited the return of Uthman, but did not come because the polytheists detained Uthman and word got out that 'Uthman had been killed. Therefore, the Prophet suggested that the Muslims do bai'at (a loyal promise) to him.

Furthermore, they pledged allegiance to the Prophet and they would fight the Quraysh with the Prophet until victory was achieved. This faithful agreement has been approved by God, as mentioned in verse 18 because it is called "Bai'atur Ridwan". This Bai'atur Ridwan trembled the polytheists, so they released 'man and sent a messenger to enter into a peace treaty with the Muslims. This agreement is known as Shulhul Hudaibiyah. Thus, there is a link between the meaning of lafadz bai' which means buying and selling with lafadz bai' which means the promise of loyalty (bai'at). The people involved in conducting bai'at are the same situation as those who carry out buying and selling activities, that is, in both activities there is a contract agreed upon by both parties. Either a 
Jurnal Ekonomi dan Perbankan Syariah

Vol. 7. No.2, 0ktober 2019: 34-46, ISSN (cet): 2355-1755 | ISSN (online): 2579-6437

contract between people who take Bai'at or a contract between the seller and buyer. Each party respects each other and does not damage the agreement for achieving objectives of the intended activity — both in terms of buying and selling or bai'at (pledge of allegiance).

\subsubsection{The Meaning of $\mathrm{Bai}^{\prime}$ in Surat al-Mumtahanah (60): 12 .}

The meaning of lafadz bai' with the disclosure of lafadz is in the form of يُبَايعُ which means the faithful promise, strengthened by its appearance in Surat al-Mumtahanah (60): 12. This verse talks about the women of faith who came to the Apostle to make a faithful promise, that they would not associate partners with God, will not steal, will not commit adultery, will not kill children, and will not lie.

\subsubsection{The Meaning of $\mathrm{Bai}^{\prime}$ in Surat at-Taubah (9): 111.}

The meaning of lafadz bai' with the expression of the lafadz in the form of ends in this verse which contains the award that Allah gives to the martyrs. The award that Allah gives is a paradise for believers who fight in the way of Allah. The mechanism for giving heaven is given in the form of a buying and selling transaction. The sellers are the mu'min who provide their souls and possessions in fighting in the way of Allah. Allah bought the souls and property of the believers who fought in His way by giving heaven. The meaning of bai 'as a buying and selling activity so closely was understood by the earliest listeners of the Quran, namely the Arab community at the time, so that the Koran uses lafadz bai' which means the sale and purchase transaction as a media that bridges understanding of exchanges between people those who strive with heaven.

Ismail bin Umar Al-Quraishi bin Kathir Al-Basri Ad-Dimasyqi in his interpretation of Allah, informs that He buys from His faithful servants, themselves, and their property, which they have sacrificed in the way of Allah with heaven. For surely, God has accepted what was sacrificed by His servants who obey Him, then exchange them for the reward that is on His side of His gift. Al-Hasan Al-Basri and Qatadah said, "Those who strive in the way of Allah, for the sake of Allah, have been buying and selling to Allah, then Allah has paid the price.

\subsection{Meaning of Tijarah in the verses of the Qur'an}

\subsubsection{The meaning of the word تجارة in Surat al-Baqarah (2) verse 282.}

In the interpretation of Al-Qurtubi this verse is to explain the sale and purchase of greetings explicitly, especially greetings carried out by the people of Medina. According to the Al-Qurthubi, the word salam is synonymous with the word salaf. If salam is used in the language of the Qur'an, salaf is used in the language of the hadith. The difference between the two is that the word salaf is more commonly used to interpret the word qard (debt), while salam is the word used for one of the types of trading allowed. [2] 
40 | Farid Ikhwanuddin, Roni Hidayat : Zahrotul Millah: Revealing the Meaning of Bai' and

Tijarah in Al-Qur'an (Interpretation of Economic Verses)

While the word تجارة in this verse by Muhammad Quraish Shihab is interpreted as trading, that is, if trading is carried out in cash, then it is proper if we do not write down the transaction, this is different from the initial fragment of the verse telling about trade in the form of debts which advocates writing تجارة accompanied by witnesses. from the transaction. The verse where the word is called surah al-Baqarah (2): 282), is the most extended verse in the Qur'an and is also known as al-mudayanah verse or verse that deals with debts. Debt-debt transactions or in fiqh terms called Al-Qardh by the scholars are allowed based on the Quran, Hadith, and ijma 'Ulama (Antonio, 2001, p.127).

Regarding debts, in a Indonesian dictionary, debts are money borrowed from others and lent to others (KBBI, 1998). In Islamic terminology, debt is known as al-Qardh which means discount (Marzuki, 1998, p.51). It is understood as assets given to people who are in debt, because the assets given are deductions from the assets of those who give debt (Husein, 1995, p.327), but in general specifically in the term Fiqh, al-Qardh is defined as a loan or debt (Mudjieh, 1994, pp. 45-64).

It related to the third point of view, which is allowed the existence of a third party in the transaction process (writing and imlak) debts. In this process, this paragraph allows third parties if one of the people in the transaction is not good at literacy, is weak in mind (not good at handling assets), or is weak, such as being old or ill, and other reasons requiring third parties in launch the transaction process. It is related to the fourth point of thought, namely the recommendation for people who owe to the creditor. Why does this suggest that the debt must be from the debt? According to Muhammad Quraish Shihab, because people who owe are in a weak position. Because if the one was giving the debt away, it could be the one who owes it to deny it. The process of reading the results of debtreceivable transactions carried out by the debtor himself in front of the writer/registrar and the creditor, then there is no reason for those who owe to deny the contents of the agreement.

It is related to the seventh point of view, which is the prohibition of making it easy in the process of the debt. As we know that debts (al-Qardh) are included in aqad taawwuni or mutual assistance agreements and not commercial transactions (Antonio, 2001, p. 51), but keep in mind this contains a suggestion to be proportional and fair. For example, do not writers and witnesses make it difficult for transactions, do not make transactions make it difficult for witnesses and writers such as delaying repayment/repayment of loans (al-Nawawi, 1994, 51). Furthermore, between those who make transactions (creditors and debtors), for example do not return the loan amount the same, wherein debts are required to return loans with the same amount (Darussalam \& Malik, 2017,45-64).

\subsubsection{The meaning of the word تجارة in Surat an-Nisa (3): 29.}

The word تجارة in this verse by Muhammad Quraish Shihab is interpreted as a trade. Trade that is blessed by God is with trade provisions based on willingness/mutual pleasure. Trade that is not following religion or the absence of coercion on the side of the transaction, including those that must be asked (creditors) where, in the previous verse fragment, the story will be canceled, and 
Jurnal Ekonomi dan Perbankan Syariah

Vol. 7. No.2, 0ktober 2019: 34-46, ISSN (cet): 2355-1755 | ISSN (online): 2579-6437

\section{1}

in this last sentence excavation to escape, to find out, anything, anything, anything, whatever is needed in life. In the previous verse (Sura An-Nisa (3): 34) discusses that marriage requires wealth, at least for the marriage and the necessities of life of husband and wife. Therefore it is natural that this verse is needed (Sura An-Nisa (3): 29), who gives guidance on the approval of property that has been wholly taken about marriage. On the other hand, the previous verses (Sura. An-Nisa (3): 24-25) also talk about the approval of assets through inheritance (Prodjodikoro, 1993: Djamali, 2002: Syaifuddin, 1982) or dowry, being discussed here Approval of assets through each business.

Through this verse (QS. An-Nisa (3): 9), Allah reminds those who believe that they can check wealth not by vanity, which is not in accordance with the guidance of the sharia (Nurhayati and Wasilah, 2011), thereby obtaining property. That is by way of commerce based on willingness not approved by religious provisions. In connection with forbidding to ask for property from vanity, agreeing to the fragment of the verse 'do not need wealth' Muhammad, Quraish Shihab agreed that using the word meal' to promote vanity wealth (one) because eating is a primary need. It is forbidden to obtain it with vanity; this cannot be separated from the definition of property, which is everything that is needed by humans to save and get.

Al-Qur' an al-Karim, in all his descriptions, including in the economic field, always pays attention to humans as a whole. So, the Quran describes its discipline by paying attention to the interests of individuals and society. The individual is seen as a whole, physically, intellectually, and spiritually, and society is confronted with the trust of weak and robust groups but does not make them in related classes discuss communism, but encourages them to help for the benefit of individuals without rejecting society or otherwise. It is still related to the first thought when the above verse will question the rules set and do not do what is termed by the above verse with (بياطل) al-bathil, related to religious provisions or requests that are approved. In this context, the Prophet SAW said, "The Muslims are following (must obey) the terms that they agreed upon as long as it was not declared as unlawful or forbidding the halal" (Shihab, 2011, pp. 45$64)$.

Furthermore, the suggestion of trading is based on willingness in fragmenting the paragraph (let) the trade based on the willingness between you is to emphasize the necessity of the willingness of both parties or as they are termed (منكم تراض عن) "interadhin minkum". Although the willingness of something abstract or hidden in the heart, indicators, and signs can be seen. Ijab and Kabul, or whatever is known in customs as handover, are forms that are and can be used in punishing and showing willingness between those who transact. In connection with the third point of view, namely the prohibition of suicide, Muhammad Quraish Shihab argues, that because property has a position below life, sometimes lives are at stake to obtain or maintain it, and in this verse (Surat 
42 | Farid Ikhwanuddin, Roni Hidayat : Zahrotul Millah: Revealing the Meaning of Bai' and Tijarah in Al-Qur'an (Interpretation of Economic Verses)

An-Nisa (3): 29) recommends not to kill yourself, or kill someone else. (Shihab, 2011, pp. 45-64).

\subsubsection{The meaning of the word تجارة in Surat at-Taubah (9): verse 24.}

The word تجارة in this verse by Muhammad Quraish Shihab is interpreted as commerce, which has a context for some things that are loved by humans. In addition to trade/business, it is mentioned that humans often neglect fathers, children, siblings, wives, relatives, assets, dwelling houses. From some of the things that are loved by these people, a Muslim who has more faith should love Allah, Rasul, and jihad in his path. For those who love more than Allah, apostles and jihad in His path can be classified as wicked and will bring torment from Him. This verse, according to Quraish Shihab, is one proof of human desire to achieve as much as possible for themselves and their families. Furthermore, this does not mean forbidding love for family, possessions, and so forth how he forbade it even though love for wealth and children is instinct (Shihab, 1996) and encouragement of human nature.

The Quran also justifies this (Surat Ali 'Imran (3): 14). This verse only reminds us not to love the eight things above beyond the limit so that he is chosen while sacrificing religious interests. The heart is like a vessel, and if there is air in it, water cannot continue to be in it. Imam Sadiq stated. "The human heart is God's residence, so do not allow anything other than Allah" (Sultan, 2004, p. 55). Indeed, love for something is measured when a person is confronted with two or more things which one must choose. In this context, if worldly pleasures are paired with Divine values, then one of them must be chosen; greater love will be seen when making choices. It should also be noted that not always worldly interests and pleasures conflict with Divine values, and at the time, there was no harm if the two were combined. Once again, the threat of the above verse is aimed at situations where a choice is required regarding two things which cannot be combined.

\subsubsection{The meaning of the word تجارة in Surat an-Nur (24): 37}

The word تجارة in this verse by Muhammad Quraish Shihab is interpreted as a trade, whereby being busy in commerce is one of the reasons in the negligence of people worshiping Allah SWT. Therefore, this verse invites humans not to be neglected in the trade (profession) and the buying and selling process that has been and will be carried out. One form that is often neglected in commerce and buying and selling is negligence in remembrance because of thinking about the advantages and disadvantages. Prayer services are busy because of the tight time in commerce and buying and selling as well as the worship of zakat, which is often forgotten or even intentionally not tithe for fear of lack of wealth. A sign for people who are always dhikr, prayer, and zakat are that they are afraid of the torment that will be inflicted on the Day of Judgment. In connection with the first point of view, namely the encouragement of remembrance, prayer and zakat in commerce and buying and selling in fragments of male verses that are not neglected by commerce and not (also) by buying and selling from zikrullah, and carrying out prayers and giving alms ... ", 
Jurnal Ekonomi dan Perbankan Syariah

Vol. 7. No.2, 0ktober 2019: 34-46, ISSN (cet): 2355-1755 | ISSN (online): 2579-6437

Muhammad Quraish Shihab quoted Ibn Asyur's words that the word الرجل rijal was understood in terms of the opposite of the word woman. This is because those who glorify in the church are monks, all of whom are men, those who concentrate in worship, so trading and trading do not neglect them from remembering Allah. Praise was given to them due to their faith when it was still considered valid and even then, the teachings of Islam they do not know (Shihab, 2011, 45-46).

Related to the second point of thought, namely the sign of the person who is remembered, prayers, zakat, and obeys Allah, where the fragment of the verse reads. On a day that (when it was) shook the heart and the viewer. The word taqallub was taken from the word (تقلب) qallaba means tossing and turning. From the same root word, the word qalb is born because the heart is alternating in nature, very happy to be very difficult, once to accept other times to reject, and so on. Conflict of eyes and hearts when it is caused by fear of facing the threat of torture on the Day of Judgment.

\subsubsection{The meaning of the word تجارة in Surat Fathir (35): 29}

In Al-Muyyasar's Tafsir that those who read the Quran and practice it, keep praying in due time, spend from what we allow them with various forms of income, both mandatory and recommended, in secret and clear. These are hoping with that a trade that does not lose and not perish, namely the pleasure of Allah to them, good luck reaching His great reward.

\subsubsection{The meaning of the word تجارة in Surat as-Shaf (61): 10}

The word in this verse by Muhammad Quraish Shihab Tijarah is interpreted as pious deeds. Indeed, the Qur'an often uses the word for this meaning because it motivates the Ummah to do good deeds is to obtain the exact rewards that a business does for someone to gain profit and calculation. Islam is a religion that can balance between the world and the hereafter between hablumminallah (relationship with God) and hablumninannas (relations between human beings). Therefore, a Muslim is guided always to balance it (the world and the hereafter), because it is not the least use of worldly terminology used in Afterlife problems such as trading with God. Quraish Shihab states, related to the following verse (ash-Shaf (61): 11), that the verse is understood that Allah invites the believers to a great trade which, if doing so can save from painful punishment. Trade is a struggle on the road Allah is to believe in Allah and His Messenger and strive, that is to be serious, from time to time to devote what you have in the form of energy, thought, time, and with your possessions and souls in the path of Allah. 
44 | Farid Ikhwanuddin, Roni Hidayat : Zahrotul Millah: Revealing the Meaning of Bai' and Tijarah in Al-Qur'an (Interpretation of Economic Verses)

\section{CONCLUSION}

Based on the analysis of scientific work above, some important conclusions can be drawn from the meaning of bai 'and pilgrimage in the Qur'an, the meaning of lafaz bai' in the Qur'an there are various variations contained in eleven verses scattered in different letters, whereas lafadz tijarah there are eight verses in the Qur'an below as the writer I will take an example of the meaning of bai,' and the pilgrimage is;

\section{The meaning of bai 'in Surah Ibrahim (14): 31}

The Lafadz used in this verse is (بيع). In this verse, we can understand the meaning of bai as a sale and purchase activity in which there is a process of exchange (redemption) of something for something. Talk about Allah's commands to establish prayers and give alms. In this verse, Allah reminds people that the deadline for people to do an action (in this case, prayer and giving alms) is with the coming of doomsday.

\section{The meaning of bai 'in Surat al-Baqarah (2): 282}

$L a f a d z$ is used in this verse by using the word; تبايع. The meaning in this paragraph is to explain the buying and selling activities that require testimony in the implementation, ordered to write honestly and fairly the transaction activities carried out.

\section{The meaning of the word تجارة in Surat an-Nisa (3): 29}

The meaning of تجارة in this verse by Muhammad Quraish Shihab is interpreted as a trade that is a trade that is approved by God is a condition of trade that is based on willingness / mutual pleasure (which does not violate religious provisions) or lack of coercion between the parties to the transaction.

\section{The meaning of the word تجارة in Surat an-Nur (24): 37}

The meaning of تجارة in this verse by Muhammad Quraish Shihab is interpreted as a trade, whereby being busy in commerce is one of the reasons in the negligence of people worshiping Allah SWT.

\section{REFERENCES}

Al-qur'an al-karim.

Abdullah Siddik Al-Haji, Inti dasar hukum dagang dalam islam (Jakarta: Balai Pustaka,1993 M), h. 8-9

Abdulllah, Taufiq et. al. (ed.), Ensiklopedi Tematis Dunia Islam, Jakarta: PT. Ictiar Baru Van Hoeve, 2002

Antonio, M. Syafi'i. (2001). Bank Syariah dari Teori ke Praktek. Jakarta: Gema Insani Press.

Beekun, D. R. I. (1996). Islamic business ethics, 20170(703).

Darussalam, A. Z., \& Malik, A. D. (2017). Konsep Perdagangan dalam Tafsir Al-Mishbah ( Paradigma Filsafat Ekonomi Qur ' ani Ulama Indonesia ), 3(1), 45-64.

Fajri, R. (2007). Sejarah keuangan islam, 173-194.

Fathoni, N. (2013). Konsep Jual Beli dalam Fatwa DSN-MUI, IV, 51-82. 
Jurnal Ekonomi dan Perbankan Syariah

Vol. 7. No.2, 0ktober 2019: 34-46, ISSN (cet): 2355-1755 | ISSN (online): 2579-6437

Fauroni, L. (2003). Rekontruksi etika bisnis prespektif al-qur'an, 4(1), 91106.

Husein, Syed Ahmad . (1995). Fiqih dan Perundang-undangan Islam. Kuala Lumpur: Dewan Bahasa dan Pustaka.

Indriyani, .Novi. (2013). Tinjauan fikih muamalah; pengetahuan masyarakat mengenai akad tabaru' dan tijarah, 89-99.

Islahi, A. A. (2010). Market and pricing mechanism in pre-classical literature, 8(22793).

Khuza, R. (2005). Etika Bisnis Dalam Islam, XXI(1), 36-48.

Lutfi, A. (2011). Penafsiran Ayat-ayat ekonomi dalam al-qur'an, 12, 26.

Marzuki, Kamaluddin A. (1998). Fiqih Sunnah. Bandung: Al-Ma'arif.

Mardani. 2011" Ayat-ayat dan hadits ekonomi syariah'h 5. Raja grafindo persada

Ma'luf, Lois, al-Munjid fî al-Lughah wa al-A'lâm, Beirut: al-Maktabah alSyarqiyyah, 2002,hlm.57

Mudjieh, M. Abdul. (1994). Kamus Istilah Fiqh. Jakarta: Pustaka Firdaus.

M. Dawam Raharjo, Islam dan transformasi sosial ekonomi (Yogyakarta: Lembaga Studi Agama dan Filsafat, 1999), h. 262.

Nawawi, Abi Zakariyah Yahya ibn Sharaf al-. (1994). Shahih Muslim bi al-Syarh al-Nawawi. Kairo: Dar al-Hadits

Nurhayati, Sri dan Wasilah. (2011). Akuntansi Syariah di Indonesia, Ed. II. Jakarta:Salemba Empat.

Nushruddin Baidan,Metodologi Penafsiran Al-Qur'ān , Jakarta, Pustaka Pelajar, 1988, hlm. 2

Prodjodikoro, Wirjono. (1993). Hukum Warisan di Indonesia. Bandung: Sumur Bandung.

Saifullah, M. (2011). Etika bisnis dalam islam praktik bisnis Rasulullah, 19, 127-156.

Siswadi. (2013). Jual beli dalam perspektif islam, III(2), 59-65.

Shihab, Muhammad Quraish. (2011). Bisnis Sukses Dunia Akhirat. Jakarta: Lentera Hati,

Syaifuddin, Amir. (1982). Pelaksanaan Hukum Kewarisan Islam dalam Lingkungan Adat Minangkabau. Jakarta: Gunung Agung.

Shihab,Muhammad Quraisy. Tafsir Al-Misbah : Pesan, Kesan, Keserasian Al-Qurean Volume 1 (Jakarta: Lentera Hati, 2002), hlm. 662663.

Sumitro, Warkum. (1997). Azas-azas Perbankan Islam. Jakarta: Raja Grafindo Persada.

Suretno, S. (2015). Jual beli dalam prespektif islam, 93-109.

Syuyuti. (1992), Tafsir Jalalain .h 209 ,juz 1.surat Ibrahim ayat 31

Syuyuti, (1992,) Tafsir jalalain h 44 , juz 1 Surat al-baqarah ayat 275

Wahyuningsih, D. (2012). Tinjauan Umum Tentang Jual beli, 17-33.

Windari. (2015). Perdagangan dalam Islam, 3, 19-35. 
46 | Farid Ikhwanuddin, Roni Hidayat : Zahrotul Millah: Revealing the Meaning of Bai' and Tijarah in Al-Qur'an (Interpretation of Economic Verses)

Yunita, D. (2016). Transaksi Jual Beli Melalui Elektronik Pada Website Online di tinjau dari aspek hukum islam, 24-25.

Zahroni, A. N. (1992). Bisnis dalam prespektif islam (Telaah Aspek Keagamaan dalam Kehidupan Ekonomi), 11. 